\title{
SISTEM REKOMENDASI PEMILIHAN SMARTPHONE ANDROID DENGAN DANA TERBATAS MENGGUNAKAN MODIFIED SIMPLE ADDITIVE WEIGHTING (M-SAW)
}

\author{
Adityo Putro Wicaksono', Albert Santoso ${ }^{2}$ \\ ${ }^{1}$ Fakultas Teknik dan informatika, Universitas AKI Semarang, email: \\ adityo.putro@unaki.ac.id \\ ${ }^{2}$ Fakultas Teknik dan Informatika, Universitas AKI Semarang, email: \\ albert.santoso@unaki.ac.id
}

\section{ARTICLE INFO}

Article history:

Received 18 Agustus 2019

Received in revised form 15 January 2020

Accepted 24 January 2020

Available online 31 January 2020

\begin{abstract}
With the development of communication technology today, the smartphone is one of the choices on communication tools that many users have now. Even now, smartphones have various types and prices that reach user needs, so that with limited funds, they can adjust it to their needs. By creating a smartphone selection recommendation systems, it can make it easier for people in determining smartphone purchases based on available funds, with features, brands, and advantages that are already sophisticated today. The recommendation system is made using a combined method called Modified Simple Additive Weighting (M-SAW), where Simple Additive Weighting (SAW) is used for weighting and normalization process, meanwhile Weighted Product (WP) is used for fixing the weight of criteria, determinating vector $S$, and ranking process. The result for best recommendation using this method is Oppo F5 Youth with score 0,444. With this recommendation results, makes the user make their decision for smartphone recommendation using this system.
\end{abstract}

Keywords: Recommendation System, Smartphone, Fund, M-SAW

\section{Pendahuluan}

Penggunaan teknologi komunikasi sekarang ini sudah menjadi kebutuhan paling utama dikerenakan padatnya kegiatan dan aktivitas sehari-hari, terutama smartphone. Smartphone sudah menjadi salah satu alat telekomunikasi yang dapat mencakup semua kebutuhan kita didalam berkomunikasi, mengumpulkan informasi, dan hiburan dengan berbagai fitur yang bermacammacam yang bisa disesuaikan dengan kebutuhan. Dengan berkembangnya smartphone, para pengembang smartphone berlomba untuk memberikan peningkatan teknologi pada smartphone sehingga memberikan kenyamanan dan kemudahan bagi pengguna.

Dengan berbagai macam tipe dan merk smartphone yang beredar, pengguna semakin bingung menentukan pilihan dalam memilih produk smartphone sesuai dengan kebutuhan dan dana yang dimiliki. Menurut survei Dailysocial.id menunjukkan pola pengguna smartphone di Indonesia dalam melakukan penentuan pemilihan Smartphone Android sebesar 67,82\% dengan harga Received Agustus 18, 2019; Revised January 15, 2020; Accepted January 24, 2020 
dibawah Rp. 3.000.000,- [1]. Hal ini membuat pengguna smartphone dengan dana terbatas, kadang salah di dalam menentukan pilihannya dikarenakan adanya keanekaragaman dalam spesifikasi smartphone, seperti perangkat keras, sistem operasi, fitur, serta harga yang tidak jauh berbeda[2], [3].

Pada penelitian sebelumnya untuk sistem rekomendasi smartphone, metode SAW diterapkan untuk membantu dalam memberikan rekomendasi untuk pemilihan smartphone secara tepat dan sesuai dengan keinginan pengguna[4]. Simple Additive Weighting ini juga dibuat dengan menggunakan kombinasi dengan metode lain dan sebagai alat bantu untuk mengambil keputusan yang tidak bersifat tetap[3]. Penggunaan SAW ini juga dapat digunakan untuk berbagai macam atribut di dalam pemilihan alternatif terbaik yang bermacam-macam dengan pembobotan nilai yang sudah ditentukan[2]. Kelebihan dari SAW dengan proses perangkingan yang simple dan sederhana, dapat diterapkan untuk kasus-kasus pengambilan keputusan seperti di dalam rekomendasi pemilihan smartphone dengan berbagai macam atribut[5], [6]. Sedangkan penggunaan Weighted Product (WP) sering digunakan karena bobot dihitung berdasarkan tingkat kepentingan dan dapat mengevaluasi kumpulan atribut dengan perkalian seluruh kiteria dengan hasil alternatif serta perpangkatan antara bobot dengan hasil perkalian alternatif [7]. Metode WP ini juga dapat digunakan di dalam membantu rekomendasi pemilihan smartphone berdasarkan apa yang dibutuhkan oleh pengguna[8], [9]. Sistem yang akan digunakan di dalam pengambilan rekomendasi, menggunakan kombinasi metode sistem pendukung keputusan antara Simple Additive Weighting (SAW) dan Weighted Product (WP), yang disebut sebagai Modified Simple Additive Weighting (M-SAW). Alasan penggunaan kombinasi metode ini antara lain adalah untuk dapat menghasilkan rekomendasi yang tepat di dalam penentuan pemilihan Smartphone untuk dana yang terbatas. Selain itu, penerapan metode Simple Additive Weighting diterapkan untuk perhitungan bobot dan normalisasi, dimana adanya pembagian antara nilai alternatif terhadap seluruh nilai terbesar maupun terkecil dari alternatif pada kriteria yang dituju dan metode Weighted Product yang menggunakan pembagian dari hasil total perkalian rating atribut dan menghasilkan nilai terbesar yang terpilih sebagai alternatif terbaik [10].

Hasil dari sistem rekomendasi dengan M-SAW berupa hasil perangkingan dalam bentuk list dengan menggunakan metode yang telah dibuat. Hasil perhitungan dengan menggunakan sample data menunjukkan bahwa nilai tertinggi dalam proses rekomendasi adalah Oppo F5 Youth dengan nilai 0,444. Sehingga Oppo F5 Youth direkomendasikan oleh sistem menjadi pilihan yang terbaik menurut hasil sistem rekomendasi.

\section{Metodologi}

Pada penelitian sebelumnya, banyak yang membahas tentang penerapan metode SAW dan WP di dalam penentuan rekomendasi ini. Dari beberapa penelitian, metode SAW yang diterapkan Abdinal membantu konsumen untuk memilih produk smartphone berdasarkan kriteria yang sudah dtentukan[6]. Sedangkan pada metode WP, dengan adanya perbaikan bobot, maka hasil perangkingan dari WP menjadi lebih baik dan dapat memperbaiki pembobotan yang dinilai belum sempurna[7]-[9].

\subsection{Keputusan}

Menurut Kusrini, dalam pemecahan masalah, tindakan yang harus dipilih didefiniskan sebagai keputusan. Keputusan bertujuan untuk mengurangi dampak masalah agar dapat mencapai kondisi yang diinginkan. Karakteristik dari keputusan antara lain: banyaknya alternatif dan variabel, adanya risiko, dan dibutuhkan adanya kecepatan, ketepatan dan keakuratan[11]. Di dalam kondisi pengambilan keputusan terdapat beberapa keadaan yang bisa terjadi, antara lain: semua pilihan alternatif dapat diketahui secara pasti jika pengambilan keputusan telah dilakukan dengan pasti, tingkat risiko terhadap pengambilan keputusan bervariasi, dan munculya alternatif yang tidak diketahui dengan jelas, jika pengambilan keputusan berada pada kondisi yang tidak pasti. Keputusan merupakan sesuatu yang membutuhkan adanya alternatif jawaban, menggambarkan

TRANSFORMATIKA Vol. 17, No. 2, January 2020: 115-123 
keadaan ataupun kondisi yang memiliki dua peluang yang di mana kondisinya bisa berupa kondisi yang baik ataupun kondisi yang buruk. Sedangkan pemecahan masalah adalah suatu tindakan untuk menekan dampak yang ditimbulkan dari sebuah kondisi yang terjadi. Dalam pengambilan keputusan, pada saat terjadi rekomendasi keputusan merupakan bagian dari sistem pendukung keputusan untuk dapat mencapai tujuan yang diinginkan.

\subsection{Smartphone}

Menurut Gary, dkk dalam bukunya yang berjudul Discovering Computer Fundamentals, Smartphone adalah telepon yang terkoneksi dengan jaringan internet yang menyediakan berbagai fitur untuk keperluan bisnis. Dengan adanya perkembangan di bidang teknologi dan komunikasi, Smartphone sekarang sudah menjadi alat komunikasi yang sangat penting dan sering digunakan saat ini. Fungsi Smartphone selain sebagai alat komunikasi, sekarang sudah menjadi sarana multimedia di berbagai bidang.

Konsumen masih minim pengetahuan mengenai adanya Smartphone dengan spesifikasi yang sesuai dengan kebutuhan dan anggaran yang mencukupi. Smartphone mempunyai berbagai macam perincian perangkat keras sebagai contoh prosesor yang digunakan, ukuran layar, kamera, media penyimpanan baik eksternal maupun internal, dan kapasitas baterai. Hal ini memberikan dampak negatif bagi konsumen dalam mengambil keputusan untuk memilih Smartphone yang sesuai dengan kebutuhan dan anggaran yang ada.

\subsection{Simple Additive Weighting (SAW)}

Berdasarkan [10], metode penjumlahan terbobot disebut metode Simple Additive Weighting. Metode ini memiliki konsep dimana mencari penjumlahan dengan nilai yang berkualitas dari alternatif terhadap setiap atribut yang ada. Pada metode SAW ini, diperlukan adanya proses normalisasi matriks keputusan (x) yang dibandingkan dengan semua peringkat alternatif yang ada ke dalam sebuah ukuran yang ditentukan.

$$
r_{i j}=\left[\begin{array}{ll}
\frac{x_{i j}}{M a x_{x_{i j}}} & \mathrm{j} \text { merupakan atribut keuntungan } \\
\frac{\operatorname{Min}_{x_{i j}}}{x_{i j}} & \mathrm{j} \text { merupakan atribut biaya }
\end{array}\right.
$$

Dengan keterangan:

$\begin{array}{cl}r_{i j} & \text { Nilai kineria ternomalisasi } \\ x_{i j} & \text { Nilai normalisasi dari alternatif } \\ & \text { terhadap atribut yang terbagi dalam } \\ & \text { baris dan kolom } \\ \operatorname{Max}_{i j} & \text { Nilai tertinggi dari alternatif dan atribut } \\ \operatorname{Min}_{i j} & \text { Nilai terendah dari alternatif dan atribut }\end{array}$

Setelah dilakukan proses perhitungan peringkat alternatif, maka nilainya tersebut akan dimasukkan ke dalam matriks ternomalisasi (r). Untuk menghitung hasil perangkingan, dapat diperoleh dengan cara penjumlahan antara perkalian tiap nilai bobot terhadap nilai yang ada pada matriks ternomalisasi (r) dengan rumus :

$$
V_{i}=\sum_{j=1}^{n} w_{j} r_{i j}
$$

Nilai V yang terbesar menunjukkan bahwa alternatif A yang akan terpilih.

Sistem Rekomendasi Pemilihan Smartphone Android Dengan Dana Terbatas Menggunakan Modified Simple Additive Weighting (M-SAW) (Adityo Putro Wicaksono) 


\subsection{Weighted Product (WP)}

Berdasarkan [10], penggunaan operasi perkalian agar penilaian atribut dapat terhubung, dan penilaian peringkat untuk setiap atribut dipangkatkan dengan bobot atribut disebut dengan metode Weighted Product (WP). Proses pada metode WP, memiliki tahapan yang sama dengan proses normalisasi. Pemilihan untuk setiap alternatif (A) ditentukan, dengan syarat untuk perpangkatan nilai bobot, jika pembobotan masuk dalam kategori cost, maka nilai pangkat dari bobot adalah minus, dan jika pembobotan masuk dalam kategori benefit, maka nilai pangkat dari bobot adalah positif:

$$
S_{i}=\prod_{j=1}^{n} x_{i j}^{w_{j}} \quad ; \text { dengan } \mathrm{i}=1,2, \ldots, \mathrm{m}
$$

Untuk nilai dari bobot setiap atribut (w), dilakukan proses perhitungan nilai masing-masing atribut dibagi dengan total bobot masing-masing atribut yang ada. Sehingga, jika dirumuskan:

$$
w_{j}=\frac{w_{j}}{\sum w_{j}}
$$

Kesimpulan untuk perhitungan perangkingan total adalah sebagai berikut:

$$
V_{i}=\frac{\prod_{j=1}^{n} x_{i j}^{w_{j}}}{\prod_{j=1}^{n}\left(x_{j}^{*}\right)^{w j}} ; \text { dengan } i=1,2, \ldots, m
$$

\subsection{Modified Simple Additive Weighting (M-SAW)}

Dalam penentuan kriteria sistem rekomendasi, ada 4 atribut yang digunakan sebagai penentuan smartphone yang akan digunakan:

1. Harga smartphone, menjadi pertimbangan pengguna didalam membeli smartphone dengan

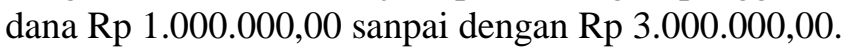

2. Kapasitas memori (RAM), menjadi pertimbangan kedua untuk kebutuhan pengguna smartphone, dikarenakan semakin besar kapasitas RAM, semakin cepat smartphone didalam membuka beberapa aplikasi. Ukuran kapasitas memori smartphone yang digunakan adalah 2GB, 3GB, 4GB, dan 6GB.

3. Kapasitas internal memori, kriteria ketiga yang dipertimbangkan untuk dipilih karena berkaitan dengan penyimpanan file seperti dokumen, video, gambar, lagu, dan yang lainnya, dengan kapasitas berukuran 16GB, 32GB, 64GB, dan 128GB.

4. Sistem Operasi menjadi pilihan keempat dalam penentuan kriteria pemilihan smartphone, karena ini merupakan bagian terpenting karena tampilan smartphone yang semakin berkembang, mulai dari Android 5.0 (Lollipop) sampai dengan Android 9.0 (Oreo).

Kemudian, untuk rancangan dari metode Modified Simple Additive Weighting (M-SAW) yang digunakan untuk sistem rekomendasi ini, dibagi menjadi dua bagian, yaitu metode SAW yang digunakan untuk proses pembobotan dan normalisasi, sedangkan metode WP digunakan untuk perbaikan bobot dan preferensi kriteria, serta proses perangkingan setelah dilakukan perhitungan bobot pada SAW. Gambaran untuk metode ini ditunjukkan pada gambar 1.

TRANSFORMATIKA Vol. 17, No. 2, January 2020: 115-123 


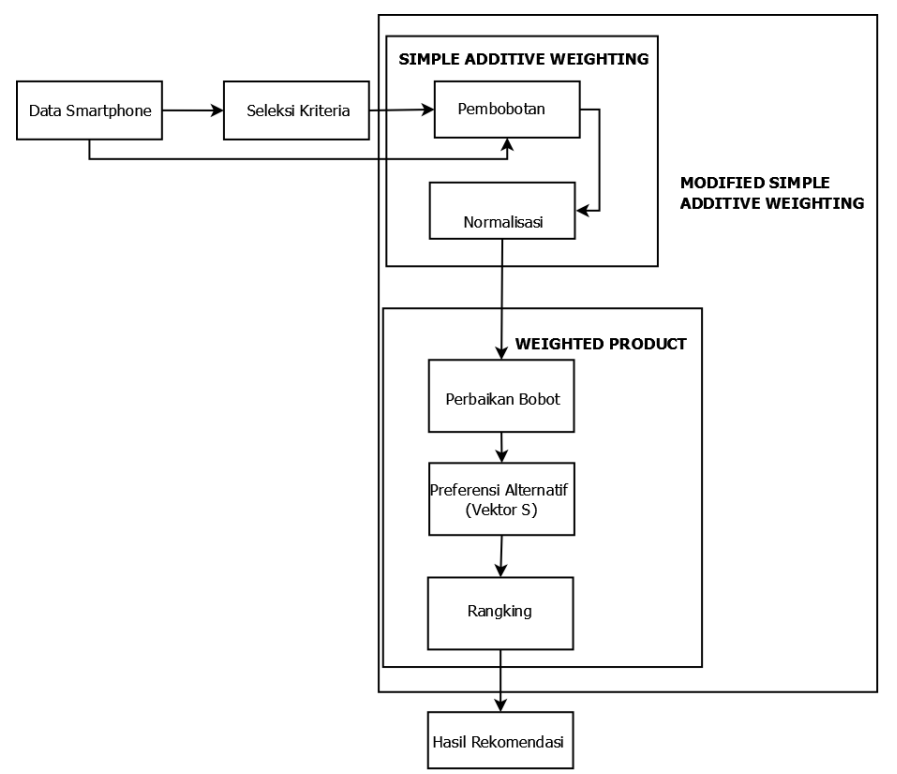

Gambar 1. Rancangan Metode Modified Simple Additive Weighting (M-SAW)

\section{Hasil dan Pembahasan}

Berdasarkan hasil observasi, maka dibuat kriteria penilaian atau bobot untuk masing-masing kriteria, dengan rincian seperti yang ditunjukkan pada tabel 1 sampai tabel 4.

Tabel 1. Kriteria Bobot Harga (C1)

\begin{tabular}{|l|c|}
\hline \multicolumn{1}{|c|}{ Bobot Kriteria } & Kriteria \\
\hline 10 (sangat baik) & $1.000 .000-1.500 .000$ \\
\hline 7,5 (baik) & $1.500 .000-2.000 .000$ \\
\hline 5 (cukup) & $2.000 .000-2.500 .000$ \\
\hline 2,5 (kurang) & $2.500 .000-3.000 .000$ \\
\hline
\end{tabular}

Tabel 2. Kriteria Bobot RAM (C2)

\begin{tabular}{|l|c|}
\hline \multicolumn{1}{|c|}{ Bobot Kriteria } & Kriteria \\
\hline 2,5 (kurang) & $2 \mathrm{~GB}$ \\
\hline 5 (cukup) & $3 \mathrm{~GB}$ \\
\hline 7,5 (baik) & $4 \mathrm{~GB}$ \\
\hline 10 (sangat baik) & $6 \mathrm{~GB}$ \\
\hline
\end{tabular}

Tabel 3. Kriteria Bobot Kapasitas Internal (C3)

\begin{tabular}{|l|c|}
\hline \multicolumn{1}{|c|}{ Bobot Kriteria } & Kriteria \\
\hline 2,5 (kurang) & $16 \mathrm{~GB}$ \\
\hline 5 (cukup) & $32 \mathrm{~GB}$ \\
\hline 7,5 (baik) & $64 \mathrm{~GB}$ \\
\hline 10 (sangat baik) & $128 \mathrm{~GB}$ \\
\hline
\end{tabular}

Tabel 4. Kriteria Bobot Sistem Operasi (C4)

\begin{tabular}{|l|c|}
\hline \multicolumn{1}{|c|}{ Bobot Kriteria } & Kriteria \\
\hline 2 (sangat kurang) & Android 5.0 \\
\hline 4 (kurang) & Android 6.0 \\
\hline 6 (cukup) & Android 7.0 \\
\hline 8 (baik) & Android 8.0 \\
\hline 10 (sangat baik) & Android 9.0 \\
\hline
\end{tabular}

Berdasarkan penentuan kriteria yang sudah ditentukan, dilakukan simulasi untuk mengetahui apakah hasil perhitungan dengan metode M-SAW sesuai dengan hasil perhitungan, diberikan data uji berupa 4 kriteria smartphone dan 3 alternatif yang akan menjadi alternatif rekomendasi keputusan. Data alternatif untuk sistem rekomendasi diperoleh dari pengumpulan data secara 
survey dan observasi melalui berbagai situs online, dan untuk data yang digunakan pada sistem rekomendasi ini sebanyak 70 data smartphone dengan list sebagai berikut:

Tabel 5. Data Merk HP Untuk Sistem Rekomendasi

\begin{tabular}{|l|l|}
\hline Data Merk HP & Jumlah Data \\
\hline Asus & 10 Data \\
\hline Lenovo & 10 Data \\
\hline Oppo & 10 Data \\
\hline Vivo & 10 Data \\
\hline Huawei & 10 Data \\
\hline Xiaomi & 10 Data \\
\hline Samsung & 10 Data \\
\hline TOTAL & 70 Data \\
\hline
\end{tabular}

Untuk alternatif yang diberikan, diambil data sampel sebanyak 3 data untuk perhitungan metode M-SAW dari merk Oppo, yaitu A1 = Oppo F5 Youth, A2= Oppo A7, dan A3=Oppo F1. Selain itu, terdapat 4 kriteria yang menjadi acuan dalam pengambilan keputusan, meliputi $\mathrm{C} 1=\mathrm{Harga}, \mathrm{C} 2=$ RAM, C3= Kapasitas Internal, dan C4= Sistem Operasi.

Berdasarkan kriteria penilaian dari masing-masing parameter pada tabel 1 sampai dengan tabel 4, didapat nilai untuk masing-masing kriteria terhadap alternatif seperti berikut:

Tabel 6. Nilai Setiap Alternatif Kriteria

\begin{tabular}{|c|c|c|c|c|}
\hline \multirow{2}{*}{ Alternatif } & \multicolumn{4}{|c|}{ Kriteria } \\
\cline { 2 - 5 } & $\mathbf{C 1}$ & $\mathbf{C 2}$ & $\mathbf{C 3}$ & $\mathbf{C 4}$ \\
\hline $\mathrm{A} 1$ & 10 & 5 & 5 & 6 \\
\hline $\mathrm{A} 2$ & 7,5 & 5 & 7,5 & 8 \\
\hline $\mathrm{A} 3$ & 5 & 7,5 & 2,5 & 2 \\
\hline
\end{tabular}

Dari tabel 6, akan ditentukan penilaian bobot terlebih dahulu. Pada metode M-SAW, untuk penentuan bobot ditentukan oleh seorang pakar, yang dimana nilai bobot ditentukan oleh hasil observasi lapangan dimana pengguna memilih tingkat kepentingan sesuai dengan kebutuhan di dalam pemilihan smartphone, yang diberikan di tabel 7 .

Tabel 7. Nilai Bobot Untuk Tiap Kriteria

\begin{tabular}{|c|c|c|}
\hline Kriteria & Nilai Bobot & Tingkat Kepentingan \\
\hline $\mathrm{C} 1$ & 5 & Sangat Penting \\
\hline $\mathrm{C} 2$ & 4 & Penting \\
\hline $\mathrm{C} 3$ & 3 & Cukup \\
\hline $\mathrm{C} 4$ & 2 & Kurang \\
\hline
\end{tabular}

Dari tabel 7, diperoleh tingkat kepentingan dari masing-masing kriteria, yaitu $\mathrm{C} 1$ (Harga) dengan bobot 5 (sangat penting), C2 (RAM) dengan bobot 4 (penting), C3 (Cukup) dengan bobot 3 (cukup), dan C4 (Sistem Operasi) dengan bobot 2 (kurang). Dari bobot pada tabel 6, akan dilakukan proses normalisasi dengan metode SAW pada persamaan (1), yang nantinya akan TRANSFORMATIKA Vol. 17, No. 2, January 2020: 115-123 
dilanjutkan pada metode WP yang digunakan untuk perbaikan bobot yang dihitung dengan persamaan (5) dengan nilai pada tabel 6. Kemudian menentukan vektor S (preferensi alternatif) untuk perangkingan alternatif menggunakan persamaan (4) dan mencari vektor $\mathrm{V}$ (hasil perangkingan) menggunakan persamaan (6).

Proses Normalisasi:

$$
\begin{aligned}
& R 11=\frac{0,25}{\max (0,25 ; 0,5 ; 1)}=\frac{0,25}{1}=1 \\
& R 12=\frac{\min (5 ; 5 ; 7,5)}{5}=\frac{5}{5}=1 \\
& R 13=\frac{\min (5 ; 7,5 ; 2,5)}{5}=\frac{2,5}{5}=0,5
\end{aligned}
$$

Hasil Normalisasi:

$$
N=\left[\begin{array}{cccc}
0,25 & 1 & 0,5 & 0,33 \\
0,5 & 1 & 0,33 & 0,25 \\
1 & 0,67 & 1 & 1
\end{array}\right]
$$

Perbaikan bobot:

Vektor S:

$$
\begin{aligned}
& w 1=\frac{5}{5+4+3+2}=\frac{5}{14}=0,357 \\
& w 2=\frac{4}{5+4+3+2}=\frac{4}{14}=0,285 \\
& w 3=\frac{3}{5+4+3+2}=\frac{3}{14}=0,214 \\
& w 4=\frac{2}{5+4+3+2}=\frac{2}{14}=0,142
\end{aligned}
$$

$$
\begin{aligned}
& S 1=\left(0,25^{(-0,357)}\right) *\left(1^{0,285}\right) *\left(0,5^{0,214}\right) *\left(0,33^{0,142}\right)=1,208 \\
& S 2=\left(0,5^{(-0,357)}\right) *\left(1^{0,285}\right) *\left(0,33^{0,214}\right) *\left(0,25^{0,142}\right)=0,622 \\
& S 3=\left(1^{(-0,357)}\right) *\left(0,67^{0,285}\right) *\left(1^{0,214}\right) *\left(1^{0,142}\right)=0,890
\end{aligned}
$$

Perangkingan $(\mathrm{V})$ :

$$
\begin{aligned}
& V 1=\frac{1,208}{1,208+0,622+0,890}=0,444 \\
& V 2=\frac{0,622}{1,208+0,622+0,890}=0,228 \\
& V 1=\frac{0,890}{1,208+0,622+0,890}=0,327
\end{aligned}
$$

Dari hasil diatas, diperoleh hasil perangkingan yang memiliki nilai paling besar adalah V1 dengan nilai tertinggi 0,444 , sehingga pada sistem merekomendasikan smartphone android yang sesuai pilihan pengguna adalah Oppo F5 Youth sebagai pilihan yang direkomendasikan. Untuk hasil rekomendasi bisa dilihat pada tabel 8 .

Tabel 8. Hasil Perangkingan Rekomendasi

\begin{tabular}{c|c|c|}
\hline Rangking Alternatif & Smartphone & Nilai Akhir (V) \\
\hline 1 & Oppo F5 Youth & 0,444 \\
\hline Sistem Rekomendasi Pemilihan Smartphone Android Dengan Dana Terbatas Menggunakan \\
Modified Simple Additive Weighting (M-SAW) (Adityo Putro Wicaksono)
\end{tabular}




\begin{tabular}{|l|l|l|}
\hline 2 & Oppo F1 & 0,327 \\
\hline 3 & Oppo A7 & 0,228 \\
\hline
\end{tabular}

Berikut hasil tampilan dari sistem rekomendasi yang telah diimplementasikan dalam website dengan implementasi metode M-SAW pada gambar 2.

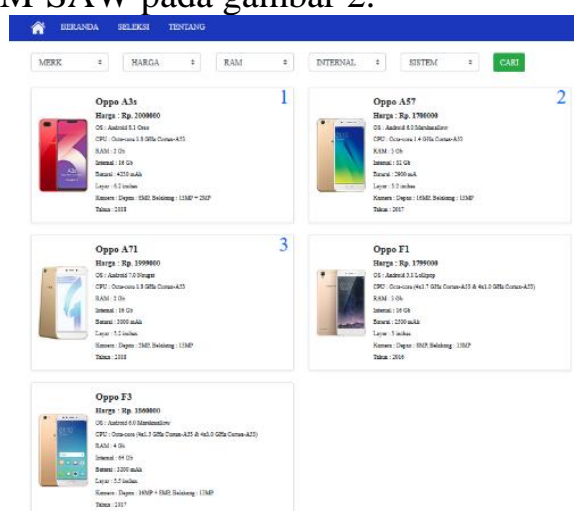

Gambar 2. Tampilan Hasil Rekomendasi pada Sistem

\section{Kesimpulan dan Saran \\ 4.1. Kesimpulan}

Berdasarkan hasil yang telah dilakukan, diambil kesimpulan bahwa pemilihan kriteria untuk pengambilan rekomendasi, dibutuhkan beberapa kriteria sebagai pertimbangan, dan dari hasil diatas menunjukkan bahwa kriteria harga mempengaruhi pertimbangan pengguna untuk memilih smartphone yang diinginkan. Diikuti dengan kriteria RAM, penyimpanan internal, dan sistem operasi sebagai pertimbangan terakhir. Dari penerapan metode Modified Simple Additive Weighting (M-SAW), SAW digunakan sebagai proses pembobotan dan normalisasi, sedangkan pada WP digunakan untuk perbaikan nilai bobot, menentukan preferensi alternatif dan perangkingan. Hasil rekomendasi yang terpilih adalah nilai $\mathrm{V}$ yang paling besar yang akan menjadi alternatif terpilih berdasarkan kriteria yang dipilih oleh pengguna. Dari hasil rekomendasi diatas, diperoleh hasil bahwa dari tiga jenis smartphone, Oppo F5 Youth menjadi pilihan rekomendasi yang memiliki nilai paling besar, yaitu 0,393, diikuti Oppo F1 dengan nilai 0,371, dan Oppo A7 dengan nilai 0,234. Sehingga Oppo F5 Youth menjadi rekomendasi yang terpilih untuk pemilihan smartphone.

\subsection{Saran}

Penelitian selanjutnya dapat mengembangkan aplikasi yang telah dibuat dengan menambahkan kriteria yang belum ada dalam sistem rekomendasi sebgai bahan pertimbangan dalam memilih smartphone, dan penyempurnaan sistem rekomendasi yang lebih baik. Serta bisa dilakukan perbandingan dengan metode gabungan lainnya sebagai pembanding dan dapat dijadikan model untuk penerapan sistem rekomendasi berikutnya.

\section{Referensi}

[1] F. Zebua, "Laporan DailySocial: Survei Pembelian Smartphone 2018," 2018. [Online]. Available: https://dailysocial.id/post/survei-pembelian-smartphone-2018. [Accessed: 13Mar-2018].

[2] A. H. Binarso F, "Sistem Pendukung Keputusan Pemilihan Gadget Smartphone Menggunakan Metode Simple Additive Weighting," Skripsi Univ. Dian Nuswantoro, 2016.

[3] P. S. Marrina; Zul, Muhammad Ihsan; Arifin, "Sistem Pendukung Keputusan untuk Pembelian Smartphone Menggunakan Metode Simple Additive Weight dan Fuzzy Associative Memory," J. Komput. Terap., vol. 2, no. 1, pp. 27-40, 2016.

[4] L. F. Rhozi, "SISTEM PENDUKUNG KEPUTUSAN PEMILIHAN SMARTPHONE

TRANSFORMATIKA Vol. 17, No. 2, January 2020 : 115-123 
ANDROID MENGGUNAKAN METODE SIMPLE ADDITIVE WEIGHTING (SAW)," Artik. Skripsi Univ. Nusant. PGRI Kediri, pp. 59-65, 2016.

[5] D. S. W. Iin Mulyadin, "Sistem Pendukung Keputusan Pemilihan Smartphone Menggunakan Metode Simple Additive Weighting," Cahaya Tech, vol. 7, no. 2, pp. 88$101,2018$.

[6] A. Mukhlasin, "Sistem Pendukung Keputusan Pemilihan Smartphone Menggunakan Metode Simple Additive Weighting (SAW) Berbasis Web," Pros. Semin. Nas. SISFOTEK, no. September, pp. 228-236, 2018.

[7] D. M. Khairina, D. Ivando, and S. Maharani, "Implementasi Metode Weighted Product Untuk Aplikasi Pemilihan Smartphone Android," J. INFOTEL - Inform. Telekomun. Elektron., vol. 8, no. 1, pp. 16-23, 2016.

[8] J. Yosef, Latif Ricaro; Susilo, "Pengembangan Aplikasi Pemilihan Smartphone Android Menggunakan Metode Weighted Product Berbasis Android," J. Inform. dan Bisnis, vol. 7, no. 2, pp. 59-65, 2016.

[9] G. M. Putra, N. Irawati, S. Informasi, and S. Royal, "Analisis Pemilihan Handphone Rekomendasi Dengan Metode Weighted Product," Semin. Nas. R. 2018, vol. 9986, no. September, pp. 199-204, 2018.

[10] R. Kusumadewi, Sri; Hartati, Sri;Harjoko, Agus; Wardoyo, Fuzzy Multi-Attribute Decision Making (Fuzzy MADM), 1st ed. Yogyakarta: Penerbit Graha Ilmu, 2006.

[11] Kusrini, Konsep dan Aplikasi Sistem Pendukung Keputusan, 1st ed. Yogyakarta: Penerbit Andi, 2007. 